\title{
PREFACE, 1970
}

The passage of twenty years and the availability of much new material have admonished me of the shortcomings of this study, but have permitted me to see it in a broader perspective. As some of the pages of this book may suggest, I was not a completely neutral and detached chronicler of the Indonesian revolution, and was at times something of a participant observer. This did, I think, help provide me with insights and information which I probably could not otherwise have obtained, but my account is undoubtedly colored by my strong sympathy for the Indonesian independence movement.

In addition, the charge has been made, particularly by Indonesians, that I have shown a partiality for the viewpoints of certain Indonesian groups-especially Soetan Sjahrir's Indonesian Socialist Party and Mohammad Natsir's wing of the Masjumi-and a lack of objectivity in my treatment of their adversaries, particularly Tan Malaka and his followers. Undoubtedly some of my views were influenced both by the personal friendships I developed with leaders of the Indonesian Socialist and Masjumi parties and by my lack of access to some other leaders. During much of my stay in the revolutionary capital, Tan Malaka as well as non-communist leaders of his political coalition were in jail and unavailable to me, and during my last months there Amir Sjarifuddin, Musso, and other leaders of the communist-led Front Demokrasi Rakjat either had been shot or were in jail. Thus, there is no doubt that the perceptions of the revolution presented in this book tend most to reflect the views of those leaders to whom I had greatest access-Soekarno and Hatta, and the leaders of the PSI, PNI, and Masjumi-parties which by the time of my arrival in Jogjakarta in mid1948 stood opposed to the communist groups.

Because it was written twenty years ago, this book has helped provide me with a better basis for appreciating an aspect of historiography to which I might otherwise have been much less sensitive. For since the year 1948-1949, when I carried out the research upon which it is based, I have had the opportunity of talking again a $t$ various intervals-five, ten, fifteen, and in some cases twenty 
years-with many of those who played central roles in the Indonesian revolution. This experience has demonstrated to me with great force what I believe is one of the salient points of historiography: that a leader's perception of his own role and even his interpretation of events in which he was intimately concerned often changes significantly over the years. It is not simply that he tends, rather naturally, to justify and put the best possible face on previous actions-but that he does this in terms of a changed political context, a different ideological climate, and altered social values. Such changes in viewpoint are, understandably, likely to influence the perception of a later generation of scholars-Indonesian as well as Western-whose research rests in part on interviews with survivors of the revolution and their later writings. In making this observation I do not mean to be critical either of these Indonesian leaders or of those who have written after me. I have a feeling that if now I were to try to rewrite this book I would myself tend to reflect something of my social and political conditioning during the time since I first visited Indonesia.

What I am here arguing for is the validity of that tenet of historiography which assigns continuing significance to on-the-spot studies made in the heat of the historical events that are being described-and thus for reprinting this early study of mine in unrevised form. While every year the scholarly productivity of what is now a considerable number of able Indonesia specialists discloses more and more the weakness of various aspects of my study, I do believe that some value and relevance will continue to attach to at least those parts of it which pertain to the revolutionary events that I actually witnessed and to the perceptions of the revolution and its social and political antecedents as related to me by Indonesian leaders in 1948 and 1949. Historical events are surely at least as well reflected by what leaders and their subordinates felt and believed at the time they were acted out as by recollections of those events many years later. And clearly documents of the revolution that have survived must be interpreted in the context of the period-as they were regarded at the time by the men who wrote them-as well as through the lenses of more detached scholars from a later and less involved generation.

There has been in recent years a large body of important research and writing on the Indonesian nationalist movement and revolution, and it has been a source of great satisfaction to me that much of it has been undertaken by former students at Cornell, with whom I have had the good fortune to work and from whom I have learned a great deal. There are, however, important gaps which remain to be filled. More work needs to be done concerning the effect of Dutch colonial rule and the Japanese occupation. Most writing about the revolution has focused almost exclusively on Java, while the importance of Sumatra in the struggle is still to be described; and almost nothing has been written on 
developments during this period in other parts of Indonesia. All too little has as yet been done on the role--political as well as military-of the army; and the parts played by both Islam and communism in the revolution deserve much greater attention. There is still a need for fuller biographical studies of the major revolutionary leaders; and scarcely anything has been written concerning Tan Malaka, Amir Sjarifuddin, and General Sudirman-important men whose lives and character have been all too little understood. Clearly there remains an enormous amount of significant research and writing yet to be carried out if our understanding of Indonesia's nationalist movement and revolution are to approximate their importance in modern Asian history.

GEORGE MCT. KAHIN

Ithaca, New York

July 30, 1970 
